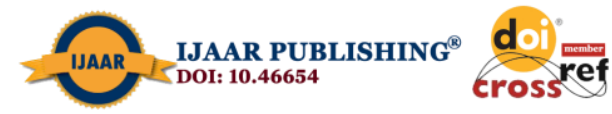

African Journal of Business and Economic Development | ISSN: 2782-7658

Journal DOI: www.doi.org/10.46654/AJBED

Vol. 1, Issue 4 (April, 2021) | www.ijaar.org

Article DOI: www.doi.org/10.46654/AJBED.1409

\title{
PETROLEUM PROFIT TAX AND PERFORMANCE OF LISTED OIL AND GAS FIRMS IN NIGERIA
}

\author{
Solomon Kumai Ngu \\ Department of Accounting, Faculty of Social and Management Sciences, \\ Greenfield University Kasarami, Kaduna, Nigeria \\ Email: Solomon.ngu@gfu.edu.ng
}

\begin{abstract}
This study examined the effect of petroleum profit tax on the performance of listed oil and gas firms in Nigeria. In achieving this objective, the ex-post facto research design was employed and secondary data were collected from the annual reports of 6 listed oil and gas firms involved in the upstream sector in Nigeria covering 2012-2018. Simple linear regression technique was used to analyze the data using Eviews to determine the effect of the independent variable (Petroleum Profit Tax) on the dependent variables (Return on Assets and Earnings per Share). Findings indicate that petroleum profit tax has a significant positive effect on earnings per share of listed oil and gas firms in Nigeria. However, petroleum profit tax has insignificant positive effect on return on assets of listed oil and gas firms in Nigeria. Based on the findings from this study, it was recommended that the Government should ensure that the tax system and rate in Nigeria are convenient for tax payers. This will reduce the incidences of tax avoidance, reduce the impact on profitability, thereby increasing shareholders' wealth. Furthermore, the Government should ensure that the revenue generated from petroleum profit tax is well utilized for the development of the economy and the general wellbeing of the citizenry.
\end{abstract}

Keywords: Petroleum profit tax, performance, oil and gas firms, return on assets, earnings per share 
Journal DOI: www.doi.org/10.46654/AJBED

Article DOI: www.doi.org/10.46654/AJBED.1409

\section{INTRODUCTION}

The role of revenue in the discharge of government duties and obligations cannot be overemphasized, because the success and survival of any country depend to a large extent on the revenue generated. Taxation remains a veritable source of government revenue both in advanced and developing nations of the world. As a result of the importance attached to taxation, fiscal policies and tax laws are carefully made by the government to ensure that the objectives of a tax system are achieved. These objectives include the provision of basic social amenities for the benefit of citizens, security of the citizens and creating a conducive environment for the stimulation of economic growth and development.

Over the years, petroleum profit tax has been a major contributor to the total tax revenue collection by the Federal Inland Revenue service. According to Usman and Adegbite (2015), the oil industry has achieved great prominence in the Nigerian economic environment since the early seventies. The government has given attention to the petroleum sector due to the huge revenue generated from petroleum profit tax. Jibrin, Ejura, and Ifurueze (2012) assert that the oil industry has become the mainstay of the Nigerian economy, generating about $85 \%$ of income for the federal government while $15 \%$ of income is generated from non-oil revenue. Statistics from the Central Bank of Nigeria revealed that as of 2000, oil and gas exports accounted for more than $98 \%$ of export earnings and about $83 \%$ of federal government revenue, as well as contributing more than $40 \%$ to the GDP. It also provides $95 \%$ foreign exchange earnings and about $65 \%$ of government budgetary revenues.

According to Gbegi, Adebisi, and Bodunde (2017), the low economic performance experienced in Nigeria despite the huge petroleum revenue cannot be attributed solely to the instability of earnings from the oil sector, but as a result of government, failure to utilize the revenue generated from the oil sector to develop other sectors of the economy. It is dismal that a country so endowed with this natural resource will still be struggling as a developing nation instead of belonging to the league of developed nations of the world.

Petroleum profit tax is a tax that is charged on the assessable profit of oil and gas companies which is $85 \%$ in Nigeria. It is worthy of note that the oil and gas sector has the highest tax rate in the country and the highest petroleum tax rate in the world. This is justified on the premise to capture the resource rent tax from the operations of the oil companies. Therefore, this study examines the effect of petroleum profit tax on the performance of listed oil and gas firms in Nigeria.

Despite the substantial amount of revenue generated through petroleum profit tax over the years, and the importance attached to taxation as a veritable source of revenue in Nigeria, yet some oil and gas firms avoid or evade tax. These companies that avoid or evade tax argue that petroleum profit tax has a huge impact on their profitability due to the high tax rate charged on assessable profit. Ilaboya and Ofiafor (2014), opines that Nigeria appears to have the highest petroleum profit tax rate of $85 \%$. The defense for this high rate is the need to capture the resource rent tax from the operations of the oil companies. Some other countries such as South Africa, Uganda, and Malaysia charge resource rent tax separately thereby reducing the petroleum profit tax rate. 
Journal DOI: www.doi.org/10.46654/AJBED

Article DOI: www.doi.org/10.46654/AJBED.1409

Several studies examined the impact of taxes on the profitability of firms in Nigeria. However, little or no empirical research has been conducted to ascertain the extent to which petroleum profit tax affect the performance of listed oil and gas firms operating in the upstream sector in Nigeria. Therefore, this study aims at examining the effect of petroleum profit tax on the performance of listed oil and gas firms in Nigeria. To achieve this objective, the following questions are asked:

What is the effect of petroleum profit tax on Return on Assets of oil and gas firms in Nigeria?

What is the effect of petroleum profit tax on Earnings per Share of listed oil and gas firms in Nigeria?

The following hypotheses are also formulated for the study:

Ho1: Petroleum profit tax does not have a significant effect on Return on Assets of oil and gas firms in Nigeria

Ho2: Petroleum profit tax does not have a significant effect on earnings per share of listed oil and gas firms in Nigeria

\section{LITERATURE REVIEW}

\section{An Overview of Petroleum Profit Tax in Nigeria}

Petroleum profit tax is one of the major taxes collected by the Federal Government of Nigeria through the Federal Inland Revenue Service. Petroleum profit tax according to Attamah (2004), is legislation that imposes a tax upon profits resulting from the mining of petroleum in Nigeria and provides for the assessment and collection thereof and the purposes connected therewith. According to Odusola (2006), petroleum profit tax is a tax applicable to upstream operations in the oil industry. It is particularly related to rents, royalties, margins and profit-sharing elements associated with oil mining, prospecting and exploration leases. Petroleum profit tax is the most important tax in Nigeria in terms of its share of total revenue contributing $95 \%$ and $70 \%$ of foreign exchange earnings and government revenue respectively.

According to Success, Success and Ifurueze (2012), due to the importance attached to oil exploration and production by the federal government of Nigeria, the taxation of petroleum profit became necessary under a tax Act different from the companies' income tax Act. This Act became effective on $1^{\text {st }}$ January 1959 since the export of oil to the international market started in 1958. This ordinance under which petroleum profit is taxed is referred to as the petroleum profit tax Act. It was first amended in January 1967 by the federal military government through decree No 1of 1967. The Act governing the taxation of petroleum profit in Nigeria in the period under review is the Petroleum Profit Tax Act 2007.

Ogbonna and Appah (2012) opine that the focus of petroleum profit tax in Nigeria is the upstream sector of the petroleum industry which deals with oil prospecting, mining, and production. The petroleum profit tax Act stipulates that crude oil production is taxed at the rate of $85 \%$ on export and $65.75 \%$ on domestic sale of oil within the periods under review. According 
Journal DOI: www.doi.org/10.46654/AJBED

Article DOI: www.doi.org/10.46654/AJBED.1409

to Lawal (2013), the Act has vested the administration of petroleum profit tax on the Federal Inland Revenue Service. The FIRS is statutorily responsible for the assessment and collection of taxes in the oil and gas sector of the economy.

Babatunde (2010) asserts that for a country that is endowed with petroleum, like Nigeria, taxation of petroleum profit is justifiable. This is because petroleum belongs to the nation, hence, the country through its government should partake of the profits from petroleum. Government, as part of its responsibilities to the nation, provides essential infrastructures that are not paid for at all except through the imposition of taxes. The government requires funds to maintain law and order and to cushion the effect of petroleum operations on the environment through antipollution programmes to make the oil region wholesome.

\section{The Objectives of Petroleum Profit Tax in Nigeria}

Azaiki and Shagari (2007) opine that countries blessed sufficient to have petroleum can base their development on this resource. They point to the potential benefits of enhanced economic growth and the creation of jobs, increased government revenues to finance poverty alleviation, the transfer of technology, the improvement of infrastructure and the encouragement of related industries. Ogbonna (2009) expressed the view that the administration of Petroleum Profits Tax in Nigeria has mainly been focused on revenue generation to the detriment of stimulating economic growth and development. According to Nwete (2004), the following are the objectives of petroleum taxation in Nigeria:

Firstly, to redistribute wealth between the wealthy and industrialized economies represented by the multinational organizations, who own the technology, expertise, and capital needed to develop the industry and the poor and emerging economies from where the petroleum resources are extracted. Secondly, the high-profit profile of successful investment in the oil industry makes it a veritable source for satisfying the government objective of raising money to meet its sociopolitical and economic obligations to the citizenry. Thirdly, the high potential for environmental pollution and degradation stemming from industry activities makes it a target for environmental taxation, as a way of regulating its activity and promoting government quest for a cleaner and healthy environment. Fourthly, to achieve the government's objective of exercising right and control over the public asset, the Government imposes very high tax as a way of regulating the number of participants in the industry and discouraging its rapid depletion to conserve some of it for the future generation. This in effect will achieve the government's aim of controlling the petroleum sector development. Finally, cleaner production may be achieved by imposing a tax on it for pollution and environmental offences. Under the petroleum Profits Tax Act of 1959 an oil company in computing its taxable profits from petroleum operations, is entitled to deduct all outgoings and expenses which are wholly, exclusively and necessarily incurred by such company for such petroleum operations.

\section{Petroleum Profit Tax Compliance in Nigeria}

Despite the importance of petroleum profit tax as a veritable source of revenue to the government, compliance by oil firms is an issue of concern. Lawal (2013) asserts that the government of Nigeria has legislative power like other countries of the world to impose any kind of tax on their citizens and at any rate appropriate. According to Babatunde (2010), it is one 
Journal DOI: www.doi.org/10.46654/AJBED

Article DOI: www.doi.org/10.46654/AJBED.1409

thing to have legislation and regulations guiding the administration, assessment, and payment of petroleum profit tax, another is the effective compliance with the law. Government, over time, issued directives and granted a concession to the petroleum companies on taxation of petroleum profit. These directives and concessions when applied directly reduce the quantum of tax payable by the petroleum companies. Babatunde (2010) further asserts that there has been reported tax avoidance and evasion by some oil companies. For example, Chevron was reported to have embroiled in a $\$ 10.8$ billion tax evasion scam following queries raised against them by ABZ integrated limited, tax consultants to the EFCC. Nigeria must have lost millions of dollars of revenue due for contractors lifting Nigeria's crude oil, who are not been assessed for tax and so have been avoiding tax payment due to the federation account.

Weak tax administration may have affected tax compliance over the years. Tax officials operate under the civil service structure with low pay when compared with the private sector. The taxpayers, principally the oil companies engage officials who are highly qualified, remunerated and motivated. The Petroleum profit tax law requires the oil companies to render returns to the Federal Inland Revenue service which is required by law to review the returns and assess the companies accordingly. There is a problem of adequate and prompt monitoring of compliance with tax laws due to the shortage of high-level manpower and lack of necessary infrastructure. Considering the rather complex fiscal regimes and perceived low knowledge of tax laws and inadequate training of tax officials, it is unclear whether the oil companies fully comply with the petroleum profit tax law (Babatunde, 2010).

\section{Petroleum Profit Tax and Performance of Oil and Gas Firms}

Very few companies, mainly multinationals are engaged in petroleum operations in Nigeria and there are also a few wholly endogenous participants. The companies operate principally under joint venture arrangements or in production sharing contracts with the federal government. The major operators include Shell, Mobil, Exxon, Chevron, Agip and Elf (Babatunde, 2010). Other oil and gas firms listed on the Nigerian stock exchange include Total Nigeria plc, Anino International, Beco petroleum product, Capital Oil, Conoil, Forte Oil, and Oando plc.

Petroleum profit tax is charged at the rate of $85 \%$ in Nigeria, as stipulated by the Petroleum Profit Tax Act. According to Abdul (2015), despite the global importance attached to taxation as a veritable source of financing developmental as well as people-oriented programmes in virtually all countries, yet a substantial number of companies in Nigeria are not willing to pay tax not minding the stiff penalties awaiting defaulters. Since petroleum tax is charged on the assessable profit of oil firms, it is argued that the high tax rate of $85 \%$ reduces the net profit of oil and gas firms immensely. Abdul (2015) further argued that oil firms that have the willingness and ability to pay petroleum profit tax still report incorrect annual income, due to the huge impact on the profitability of the business and the amount of business investment. However, a lower tax burden allows a company to lower prices or generate higher revenue which can then be paid out in wage, salaries, and/or dividends. Ezugwu and Akubo (2014) assert that a lower petroleum profit tax rate will encourage oil and gas firms to pay their tax because lower rates will have less impact on their profitability.

The relationship between petroleum profit tax and profitability have not been adequately examined by researchers. However, few studies examined the relationship between petroleum 
Journal DOI: www.doi.org/10.46654/AJBED

Article DOI: www.doi.org/10.46654/AJBED.1409

profit tax and the profitability of oil and gas companies. For instance, Gbegi, Adebisi, and Bodunde (2017) examined the effect of petroleum profit tax on the profitability of listed oil and gas companies in Nigeria using both descriptive statistics and multiple regression to analyze the data collected. It was discovered that petroleum profit tax has a significant effect on the profitability of oil and gas companies in Nigeria. Abdul and Adelabu (2015) examined the relationship between corporate tax and profitability; a case study of Oando plc from 1999-2013, and analyzed using regression. It was found that there is a positive and significant relationship between petroleum profit tax and profitability. It was concluded that corporate tax is a crucial factor affecting profitability. Ezugwu and Akubo (2014) researched the effect of high corporate tax rate on the profitability of corporate organisations in Nigeria, which was analysed using regression. The analysis of data revealed a direct positive relationship between corporate tax rate and realized profit.

Babatunde (2010) researched the perception of petroleum profit tax compliance in Nigeria. It was discovered that the level of compliance is not adequate due to the weak tax administration of petroleum profit tax.

Several studies focused on the effect of petroleum profit tax on economic growth and development. For instance, Ilaboya and Ofiafor (2014) in their study on petroleum profit tax and economic growth in Nigeria, using a time series of 32 years and analysed through a combination of co-integration and error correction estimation techniques, it was discovered that petroleum profit tax has a statistically significant positive relationship with real GDP growth rate and a positive impact on economic growth in Nigeria. Success, Success and, Ifurueze (2012) conducted a study on the impact of petroleum profit tax on the economic development of Nigeria for the period of 2000-2010 and analysed using the ordinary least square method. It was discovered that petroleum profit tax impacts positively on the gross domestic product of Nigeria and it is statistically significant. In their study on petroleum profit tax and economic growth in Nigeria, for the period 1970-2010 and analysed using relevant econometric tests, Appah and Ebiriuga (2012) discovered a long-run relationship between economic growth and petroleum profit tax. It was also found that petroleum profit tax does granger cause gross domestic product of Nigeria. Usman and Adegbite (2015) in their research on the impact of petroleum profit tax on economic growth in Nigeria, using a co-integration analysis, discovered that petroleum profit tax has a significant impact on GDP both in the short run and in the long run. Olatunji and Adegbite (2014) researched the effect of petroleum profit tax, interest rate and money supply in the Nigerian economy using a multiple regression technique to analyse the relationship among the variables. The results show that the short-run effect of petroleum profit tax was positive, while that of interest rate was negative, and the effect of the money supply was positive on economic growth.

\section{Theoretical Framework}

The theoretical underpinning of this work is the socio-political theory of taxation and the expediency theory. 
Journal DOI: www.doi.org/10.46654/AJBED

Article DOI: www.doi.org/10.46654/AJBED.1409

\section{The Socio-Political Theory}

The socio-political theory states that social and political objectives should be the major factors in selecting taxes. The theory advocates that a tax system should be designed not to serve individuals, but should be used to cure the ills of society as a whole (Ogbonna and Appah, 2012). Since petroleum is the main source of government revenue in Nigeria, it should be designed and administered in such a way that will cure the ills of the society and enhance economic growth and development. This theory is relevant to this study because the taxation of petroleum profit should be aimed at curing the ills of society as a whole and not to serve the individual interest.

\section{Expediency Theory}

This theory asserts that every tax proposal or system must pass the test of practicality. It must be the only consideration weighing with the authorities in choosing a tax proposal (Chigbu, Akujuobi, and Appah, 2012). This assertion is valid since it will be useless to have a tax that cannot be levied and collected efficiently. The Petroleum Profit Tax Act should be practicable, convenient, and result-driven.

\section{METHODOLOGY}

This study is designed to ascertain the effect of petroleum profit tax on the performance of listed oil and gas firms in Nigeria. The ex-post facto research design was adopted for this study because the event investigated had already taken place and the data used are already in existence. Secondary data was used for the study which was sourced from annual reports and accounts of the targeted oil and gas companies for the period of 7 years (2012-2018). The population of the study consists of the 54 oil and gas companies directly involved in the exploration and production (Upstream) of oil and gas in Nigeria as reported by JarusHub (2014). However, some filters were used in selecting the sample of the study. Firstly, the oil and gas firms must be quoted in the Nigerian stock exchange. Secondly, they must not have been delisted for the period under review. Thirdly, their financial statements must be available for the period under review. Thus, 6 sampled companies were selected which are, ExxonMobil Oil Plc, ConocoPhillips, Total Plc, Niger Delta Exploration and Production Plc, Seplat Plc and Lekoil Plc. A simple linear regression technique was employed to analyse the data collected using Eviews.

The model for the study is specified below:

$\mathrm{ROAi}=\beta \mathrm{o}+\beta 1 \mathrm{PPT} i \mathrm{i}+\varepsilon \mathrm{i}$

$\mathrm{EPSi}=\beta o+\beta 1 \mathrm{PPT} i \mathrm{i}+\varepsilon i$

Where,

$\mathrm{ROA}=$ Return on Assets; EPS $=$ Earnings Per Share; PPT $=$ Petroleum Profit Tax; $\beta o=$ The intercept term; $\beta 1=$ The regression coefficient; $\varepsilon i=$ Error term; $\grave{\imath}=$ Time dimension 
Journal DOI: www.doi.org/10.46654/AJBED

Article DOI: www.doi.org/10.46654/AJBED.1409

\section{RESULTS AND DISCUSSION}

This section deals with the presentation, analysis and interpretation of data generated for the study. Petroleum profit tax represents the independent variable while Return on Assets (ROA) and Earnings Per Share (EPS) which are proxies of profitability represent the dependent variables.

\section{Descriptive Statistics}

Table 1 shows the result of the descriptive statistics of the variables used in this study. It captured the mean, minimum, maximum, standard deviation and other statistics.

Table 1: Descriptive Statistics

\begin{tabular}{|l|c|l|c|}
\hline & ROA & EPS & PPT \\
Mean & 0.104286 & 6.976667 & 371625.9 \\
Median & 0.055000 & 4.755000 & 31853.75 \\
Maximum & 1.350000 & 43.58000 & 17300115 \\
Minimum & -0.210000 & -3.580000 & -15910731 \\
Std. Dev. & 0.241481 & 9.539354 & 5994732. \\
Skewness & 3.464539 & 1.815166 & -0.517527 \\
Kurtosis & 18.23050 & 6.797285 & 5.527600 \\
& & & \\
Jarque-Bera & 489.9657 & 48.29769 & 13.05517 \\
Probability & 0.000000 & 0.000000 & 0.001463 \\
& & & \\
Sum & 4.380000 & 293.0200 & 15608287 \\
Sum Sq. Dev. & 2.390829 & 3730.971 & $1.47 \mathrm{E}+15$ \\
& & & \\
Observations & 42 & 42 & 42 \\
\hline
\end{tabular}

Source: Author's computation using Eviews version 10.

The result of the descriptive statistics presented in table 1 reveals the mean, minimum, maximum, standard deviation and other statistics of the data used for the study. Result shows that the average value of petroleum profit tax for the period under review amount to $\$ 371,625.9$ billion. The minimum value of petroleum profit tax is 15910731 billion, while the maximum value is 17300115 billion. The average return on assets in the years under review amounted to 0.104286 . The minimum return on assets is -0.210000 indicating a negative return, while the maximum return on assets is 1.350000 . Similarly, the average earnings per share stood at 6.976667. The minimum earnings per share is -3.580000 (negative), while the maximum stood at 43.58000 for the period under review. 
Journal DOI: www.doi.org/10.46654/AJBED

Article DOI: www.doi.org/10.46654/AJBED.1409

Table 2: Regression result on the relationship between Petroleum Profit Tax and Return on Assets

Dependent Variable: ROA

Method: Panel Least Squares

Date: 04/21/20 Time: 13:45

Sample: 20122018

Periods included: 7

Cross-sections included: 6

Total panel (balanced) observations: 42

\begin{tabular}{lcccl}
\hline \hline Variable & \multicolumn{2}{l}{ Coefficient Std. Error } & t-Statistic & Prob. \\
\hline \hline C & 0.100116 & 0.036302 & 2.757842 & 0.0087 \\
PPT & $1.12 \mathrm{E}-08$ & $6.12 \mathrm{E}-09$ & 1.834443 & 0.0740 \\
\hline \hline R-squared & 0.776001 & Mean dependent var & 0.104286 \\
Adjusted R-squared & 0.545041 & S.D. dependent var & 0.241481 \\
S.E. of regression & 0.234803 & Akaike info criterion & -0.013692 \\
Sum squared resid & 2.205298 & Schwarz criterion & 0.069054 \\
Log likelihood & 2.287528 & Hannan-Quinn criter. & 0.016638 \\
F-statistic & 3.365180 & Durbin-Watson stat & 1.164754 \\
Prob(F-statistic) & 0.074034 & & \\
\hline \hline
\end{tabular}

Source: Author's computation using Eviews version 10.

The $\mathrm{R}$ square (coefficient of determination) in the results above is 0.776 which shows that the petroleum profit tax explains $77.6 \%$ variations in return on assets. The Durbin-Watson statistics at 1.165 indicate the absence of serial correlation. The coefficient of the F statistics at 3.365 and its corresponding p-value at 0.074 shows that the model is positive but not statistically significant at 5\% level of significance. Therefore the null hypothesis is not rejected which states that petroleum profit tax has no significant effect on return on assets of listed oil and gas firms in Nigeria. 
Journal DOI: www.doi.org/10.46654/AJBED

Article DOI: www.doi.org/10.46654/AJBED.1409

Table 3: Regression result on the relationship between Petroleum Profit Tax and Earnings Per Share

Dependent Variable: EPS

Method: Panel Least Squares

Date: 04/21/20 Time: 13:53

Sample: 20122018

Periods included: 7

Cross-sections included: 6

Total panel (balanced) observations: 42

\begin{tabular}{lrlll}
\hline \hline \multicolumn{1}{c}{ Variable } & Coefficient & Std. Error & t-Statistic & Prob. \\
\hline \hline \multicolumn{1}{c}{ C } & 6.641994 & 1.231046 & 5.395405 & 0.0000 \\
\multicolumn{1}{c}{$9.01 \mathrm{E}-07$} & $2.07 \mathrm{E}-07$ & 4.341401 & 0.0001 \\
\hline \hline R-squared & 0.520280 & Mean dependent var & 6.976667 \\
Adjusted R-squared & 0.503287 & S.D. dependent var & 9.539354 \\
S.E. of regression & 7.962435 & Akaike info criterion & 7.033795 \\
Sum squared resid & 2536.015 & Schwarz criterion & 7.116541 \\
Log likelihood & -145.7097 & Hannan-Quinn criter. & 7.064125 \\
F-statistic & 18.84777 & Durbin-Watson stat & 1.693985 \\
Prob(F-statistic) & 0.000094 & & & \\
\hline \hline
\end{tabular}

From the results presented in table 3 above, the R square at 0.520 shows that the petroleum profit tax explains 52\% variations in earnings per share. The Durbin-Watson Statistics at 1.694 indicate the absence of serial correlation. The F statistics at 18.848 and its corresponding p-value at 0.000 shows that the model is statistically significant at $1 \%$ level of significance. Therefore the null hypothesis is rejected which states that petroleum profit tax has no significant effect on earnings per share of listed oil and gas firms in Nigeria.

Findings from this study support the findings of other researchers like Gbegi, Adebisi and Bodunde (2017); Abdul and Adelabu (2015) who discovered that petroleum profit tax has positive significant effect on the profitability of oil companies in Nigeria.

\section{CONCLUSION AND RECOMMENDATIONS}

This research study examined the effect of petroleum profit tax on the performance of listed oil and gas firms operating in the upstream sector in Nigeria for a period of 7 years (2012-2018). Petroleum profit tax is a veritable source of government revenue and a tool for economic growth and development. However, the high tax rate charged on petroleum profit has a huge impact on the profitability of oil and gas companies in Nigeria. Based on the findings of this study it is concluded that petroleum profit tax has positive insignificant effect on return on assets of listed oil and gas firms in Nigeria. However, petroleum profit tax has significant positive effect on 
Journal DOI: www.doi.org/10.46654/AJBED

Article DOI: www.doi.org/10.46654/AJBED.1409

earnings per share of listed oil and gas companies in Nigeria. Therefore, the following recommendations are made:

I. The government should ensure that the tax system and rate in Nigeria are convenient for tax payers. This will reduce the incidences of tax avoidance, reduce the impact on profitability, thereby increasing shareholders' wealth.

II. The government should also ensure that the revenue generated from petroleum profit tax is well utilized for the development of the economy and the general wellbeing of the citizenry. It is pathetic that despite this great natural resource in Nigeria, the country is still lagging economically. 
Journal DOI: www.doi.org/10.46654/AJBED

Article DOI: www.doi.org/10.46654/AJBED.1409

\section{REFERENCES}

Abdul, A., and Adelabu, I.T. (2015). Relationship between Corporate Tax and Profitability: A Case Study of Oando Plc. International Journal of Education and Innovation, 1(6), 1-9.

Appah, E., and Ebiringa, O.T. (2012). Petroleum Profit Tax and Economic Growth in Nigeria. International Journal of Management Sciences and Business Research, 1(9), 12-22.

Attama .N. (2004), Taxation and Fiscal Policy, Enugu, Nigmos Publishers.

Azaiki, S. and Shagari, S. (2007). Oil, Gas and Life in Nigeria, Ibadan: Y-Books, a division of Associated Books Makers of Nigeria.

Babatunde, T.O. (2010). Perception of Petroleum Profit Tax Compliance in Nigeria (Doctoral thesis, Bournemouth University). Retrieved from http://eprints.bournemouth.ac.uk/17520/

Ezugwu, C.I., and Akubo, D. (2014). Analysis of the Effect of High Corporate Tax Rate on the Profitability of Corporate Organisations in Nigeria. Mediterranean Journal of Social Sciences, 5(20), 310-321.

Gbegi, D.O., Adebisi, J.F., Bodunde, T. (2017). The Effect of Petroleum Profit Tax on the Profitability of Listed Oil and Gas Companies in Nigeria. American International Journal of Social Science, 6(2), 40-46.

Ilaboya, O.J., and Ofiafor, E. (2014). Petroleum Profit Tax and Economic Growth in Nigeria. British Journal of Business and Management Research, 1(2), 55-67.

JarusHub (2014). List of oil and gas companies in Nigeria and difference between upstream and downstream and servicing. Retrieved from https://www.jarushub.com/list-of-oil-gascompanies-in-nigeria-and-difference-between-upstream-downstream-and-servicing/\#

Lawal, K.T. (2013). Taxation of Petroleum Profit under the Nigeria's Petroleum Profit Tax Act. International Journal of Advanced Legal Studies and Governance, 4(2), 1-17.

Nwete, B.O. (2004), "How can Tax Allowances Promote Investment in Nigerian Petroleum Industry”bonlaw@yahoo.co.uk

Odusola, A. (2006). "Tax policy reforms in Nigeria", World Institute for Development Economics and Research, Research Paper No. 2006/03. http://www.wider,unu.edu

Ogbonna, G. N. (2009) "Burning Issues and Challenges of the Nigerian Tax Systems with Analytical Emphasis on Petroleum Profits Tax". International Journal of Accounting, Finance, \& Economics Perspectives, 1(1), 2009.

Ogbonna, G.N., and Appah, E. (2012). Petroleum Income and Nigeria Economy: Empirical Evidence. Arabian Journal of Business and Management Review, 1(9), 33-59.

Olatunji, T.E., and Adegbite, T.A. (2014). The Effects of Petroleum Profit Tax, Interest Rate and Money Supply on the Nigerian Economy. Global Journal of Commerce and Management Perspective, 3(3), 81-87. 
Journal DOI: www.doi.org/10.46654/AJBED

Article DOI: www.doi.org/10.46654/AJBED.1409

Success, M.J., Success, E.B., and Ifurueze, M.S.K. (2012). The Impact of Petroleum Profit Tax on Economic Development of Nigeria. British Journal of Economics, Finance and Management Sciences, 5(2), 60-70.

Usman, O.A., and Adegbite, T.A. (2015). The Impact of Petroleum Profit Tax on Economic Growth in Nigeria: The Co-integration Analysis. $18^{\text {th }}$ International Academic Conference, London. DOI: 10.20472/IAC.2015.018.095 